Vol. 1, No. 1, Juni 2020

\title{
SPEKTA
}

Jurnal Pengabdian Kepada Masyarakat : Teknologi dan Aplikasi

Journal homepage :

http://journal2.uad.ac.id/index.php/spekta

\section{PENCEGAHAN DEMAM BERDARAH PADA MASYARAKAT DUSUN MONGKRONG GUNUNG KIDUL}

\section{Alfian Rahmawan, Farid Ma'ruf*}

Program Studi Teknik Industri, Universitas Ahmad Dahlan, Jalan Ringroad Selatan, Bantul, Daerah Istimewa Yogyakarta, Indonesia

\section{INFO ARTIKEL}

Diterima : Mei, 2020

Direvisi : Juni, 2020

Disetujui : Juni, 2020

\section{Keywords:}

DBD;

Aedes Aegypti;

$3 \mathrm{M}$

Death;

Prevent;

\begin{tabular}{l} 
ABSTRACT \\
\hline Demam Berdarah Dengue (DBD) is an infectious disease \\
by the dengue virus, which is transmitted through the bite \\
of Aedes aegypti mosquitoes. This disease's \\
characteristics include sudden high fever accompanied \\
by bleeding manifestations and the tendency to cause \\
shock that can cause death. Until now, there is no cure \\
for dengue fever or a vaccine. Therefore, the only way to \\
prevent this disease is to break the chain of transmission. \\
The main factor of dengue fever in Indonesia is the Aedes \\
aegypti mosquito. Another way to avoid dengue fever is \\
conducted the correct $3 M$ plus method. The first method \\
is "Close" which means cover all places that can hold \\
water, both inside and outside the house. The second \\
method is "Drain" which means drain water reservoirs \\
such as bathtubs, aquariums, and flower vases two times \\
a week. The mosquito metamorphosis cycle, from egg to \\
adult mosquito, lasts 8 -10 days. 3. The last method is \\
"Bury" which means bury all objects that can hold \\
water, such as used cans or plastic containers. However, \\
in the 3M movement, which has been renewed to 3M plus, \\
this third M is no longer recommended because it can \\
cause soil pollution.
\end{tabular}

\section{PENDAHULUAN}

Demam berdarah Dengue (DBD) merupakan salah satu penyakit menular yang masih menjadi masalah kesehatan masyarakat. Di Yogyakarta, jumiah kasus setiap tahun cenderung semakin meningkat dan persebarannya semakin luas. Keberhasilan program pencegahan DBD tergantung dari cara masyarakat memahami pentingnya upaya pelaksanaan Pemberantasan Sarang Nyamuk (PSN) di lingkungan masing-masing, terutama dengan langkah-langkah Menutup, Menguras, dan Mengubur (3M) plus yang benar. Langkah pertama adalah menutup, dimana masyarakat harus menutup segala tempat yang bisa menampung air, baik di dalam maupun di luar rumah. Jika tidak

\footnotetext{
* Corresponding author.

E-mail address: farid.maruf@ie.uad.ac.id

https://doi.org/10.12928/J.spekta.v1i1.2696
} 
diperlukan, tengkurapkan wadah-wadah yang bisa menampung air di luar rumah agar tidak tergenangi air hujan. Nyamuk betina memanfaatkan air yang tergenang sebagai tempat bertelur. Langkah kedua adalah menguras dengan membersihkan tempat-tempat penampungan air seperti bak mandi, akuarium, dan vas bunga satu hingga dua kali seminggu. Siklus metamorfosis nyamuk, mulai dari telur hingga menjadi nyamuk dewasa, berlangsung selama 8-10 hari. Dengan mengosongkan tempat-tempat penampungan air secara berkala, Anda memutus siklus hidup nyamuk. Langkah terakhir adalah mengubur semua objek yang bisa menampung air, seperti kaleng bekas atau wadah plastik. Namun, dalam gerakan 3M yang telah diperbaharui (3M plus), $\mathrm{M}$ yang ketiga ini tidak lagi dianjurkan karena menimbulkan polusi tanah. Kini, pemerintah menganjurkan untuk mendaur ulang sampah-sampah anorganik yang bisa menampung air (Husna, dkk, 2016).

Pencegahan dan pemberantasan kejadian luar biasa (KLB) DBD tidak dapat dicapai tanpa kerja sama dan keterlibatan masyarakat pada setiap kampanye pencegahan dan penanggulangan DBD. Masyarakat didorong untuk mengambil tindakan PSN, seperti menguras penampungan air, membersihkan sampah padat, mencegah perkembangbiakan vektor, dan melakukan upaya perlindungan diri dari gigitan nyamuk (Clano et al, 2006). Setiap program kampanye pemberantasan DBD akan dapat berhasil jika masyarakat memahami pentingnya manfaat program pencegahan yang harus dilaksanakan.

Studi terdahulu menjelaskan bahwa pendidikan kesehatan tentang PSN DBD mampu meningkatkan pengetahuan masyarakat terhadap penyakit DBD, namun belum sepenuhnya ditunjukkan ke dalam perilaku pencegahan yang nyata (Spiegel et al, 2005). Permasalahan yang sering terjadi dalam pelaksanaan PSN adalah masyarakat tampaknya belum banyak memiliki pemahaman yang tepat dan benar tentang pencegahan dan pengendalian vektor DBD. Hal ini sering ditunjukkan dengan kegiatan kebersihan yang terkadang-kadang salah sasaran.

Penyakit DBD adalah penyakit infeksi oleh virus dengue yang ditularkan melalui gigitan nyamuk Aedes, dengan ciri demam tinggi mendadak disertai manifestasi perdarahan dan bertendensi menimbulkan renjatan (shock) dan kematian. Sampai sekarang penyakit DBD belum ditemukan obat maupun vaksinnya, sehingga satu-satunya cara untuk mencegah terjadinya penyakit ini dengan memutuskan rantai penularan yaitu dengan pengendalian vektor. Vektor utama penyakit DBD di Indonesia adalah nyamuk Aedes aegypti. Tempat yang disukai sebagai tempat perindukannya adalah genangan air yang terdapat dalam wadah (kontainer) tempat penampungan air artifisial misalnya drum, bak mandi, gentong, ember, dan sebagainya; tempat penampungan air alamiah misalnya lubang pohon, daun pisang, pelepah daun ke ladi, lubang batu, ataupun bukan tempat penampungan air misalnya vas bunga, ban bekas, botol bekas, tempat minum burung dan sebagainya (Soegijanto, 2016). Hasil survei Departemen Kesehatan RI di 9 kota besar di Indonesia pada tahun 1986-1987 menunjukkan bahwa satu diantara tiga rumah maupun tempat umum ditempati jentik nyamuk Aedes. Disamping itu, pengetahuan, sikap, dan perilaku masyarakat tentang pencegahan penyakit DBD pada umumnya sangat kurang (Depkes, 1993).

Upaya pemberantasan penyakit, baik itu menyangkut pencegahan, pengobatan, maupun rehabilitasi selalu melibatkan perempuan, khususnya ibu rumah tangga. Keterampilan merawat kesehatan keluarga dipengaruhi oleh pengetahuan dan pengalaman seseorang. Mereka yang memiliki banyak pengetahuan, sikap pengetahuan akan lebih terampil daripada yang kurang, dengan demikian pengetahuan akan mempengaruhi bagaimana perempuan memperlakukan diri dan keluarganya terkait dengan penyakit. 


\section{METODE PELAKSANAAN}

Penelitian telah dilaksanakan pada bulan Februari 2019 di Desa Sampang, Dusun Mongkrong Kabupaten Gunung Kidul Provinsi Yogyakarta. Penelitian dilakukan dengan cara metode survey dan secara observasional dengan desain cross-sectional. Instrumen pada penelitian ini yaitu kuesioner PSP tentang cara pencegahan DBD, sedangkan metode survei mahasiswa mealakukan pengecekan bak mandi atau penampungan air yang ada di rumah warga . Sampel penelitian untuk pengumpulan data pengetahuan dan perilaku adalah individu dalam rumah tangga yang terpilih secara acak sebanyak 50 orang yang ada di wilayah tersebut. Dengan asumsi tingkat signifikansi 5\%, maka jumlah minimal sampel yang diperlukan adalah 35 .

\section{HASIL DAN PEMBAHASAN}

Hasil penelitian ini menunjukan secara umum pengetahuan masyarakat tentang demam berdarah bisa dikatakan kurang tentang pencegahan dan pengendalian DBD. Masyarakat masih membutuhkan informasi tentang pengenalan nyamuk vektor. Nyamuk memang dihubungkan dengan penularan penyakit, akan tetapi spesifikasi jenis, ciri dan perilaku serangga tersebut perlu disosialisasikan lebih lanjut kepada masyarakat di Kelurahan Kutowinangun. Sangat penting bagi setiap rumah tangga untuk mampu mengidentifikasi dengan benar nyamuk Aegypti dan habitatnya agar dapat mengeliminasi tempat-tempat perindukan yang tepat.

Pengenalan vektor sangat berhubungan dengan pelaksanaan langkah-langkah PSN yang benar agar dapat memutus perkembangan vektor secara efektif. Pelaksanaan kegiatan kebersihan masyarakat yang dilakukan selama ini untuk gerakan PSN adalah membersihkan saluran pembuangan limbah, drainase dan sampah di lingkungan mereka, sedangkan tempat penampungan air sebagai habitat perkembangbiakan nyamuk DBD tidak tersentuh (Lloyd dan Parks, 2004).

Pengetahuan DBD ternyata lebih banyak dimiliki oleh kelompok usia lebih matang yang memiliki pengalaman lebih banyak dari pada kelompok ibu-ibu muda. Faktor demografi seperti umur, status ekonomi, pekerjaan dan pendidikan dapat berpengaruh pada perilaku seseorang. Kelompok ibu rumah tangga menunjukkan pengetahuan yang baik kemungkinan karena mereka lebih banyak memiliki waktu untuk memperhatikan masalah DBD. Demikian juga, kelompok wiraswasta/pedagang yang umumnya hanya bekerja paruh waktu. Ibu rumah tangga dapat menjadi sasaran utama dari program promosi kesehatan untuk upaya pencegahan DBD di lingkungan keluarga di Dusun Sampang. Peran perempuan di dalam pengendalian demam berdarah cukup besar. Perempuan lebih menganggap demam berdarah sebagai masalah yang penting karena dari sisi ekonomi, emosi, dan dampak terhadap kesehatan keluarga. Perempuan lebih perhatian dari pada laki-laki tentang penanganan sampah rumah tangga dan pembuangan genangan air (Perez-Guerra et al, 2009).

\section{KESIMPULAN}

Tidak ada hubungan yang signifikan antara pengetahuan dan sikap masyarakat dengan perilaku pencegahan DBD. Sebagian besar pengetahuan ibu rumah tangga tentang penyakit DBD sudah cukup baik namun pengetahuan tentang nyamuk vektor masih kurang. Sikap masyarakat akan upaya pencegahan DBD masih butuh ditingkatkan. 
Perilaku pengendalian vektor lebih banyak dilakukan di dalam mmah. Program promosi kesehatan yang disarankan dapat difokuskan pada kegiatan pengenalan vektor dan upaya pengendalian baik di dalam maupun di luar lingkungan rumah. Metode PSN di lingkungan masing-masing, dengan menggunakan langkah-langkah 3M plus yang benar. Namun, dalam gerakan $3 \mathrm{M}$ yang telah diperbaharui menjadi $3 \mathrm{M}$ plus, $\mathrm{M}$ yang ketiga ini tidak lagi dianjurkan karena menimbulkan polusi tanah. Kini, pemerintah menganjurkan untuk mendaur ulang sampah-sampah anorganik yang bisa menampung air.

\section{DAFTAR PUSTAKA}

Clano, Kawa, Cavalini \& Rosa. (2006). Community participation in dengue, Brazil. Dengue Buletin. Geneva:WHO.

Depkes RI. (1993). Keputusan Direktur Jenderal Pemberantasan Penyakit Menular dan Penyehatan Lingkungan Pemukiman Tentang Persyaratan Petunjuk Teknis Tata Cara Penyehatan Lingkungan Rumah Sakit.

Husna, R. N., Wahyuningsih, N. E., \& Dharminto, D. (2016). Hubungan Perilaku $3 m$ Plus Dengan Kejadian Demam Berdarah Dengue (Dbd) Di Kota Semarang (Studi Di Kota Semarang Wilayah Atas). Jurnal Kesehatan Masyarakat (e-Journal), 4(5), 170-177.

Lloyd, L. S., Winch, P., Ortega-Canto, J., \& Kendall, C. (1994). The design of a communitybased health education intervention for the control of Aedes aegypti. The American Journal of Tropical Medicine and Hygiene, 50(4), 401-411.

Lloyd LS. dan Parks, W.J., (2004). Planning Social Mobilization and Communication for Dengue Fever Prevention and Control: A Step-bystep Guide. Geneva: World Health Organization.

Pérez-Guerra, C. L., Zielinski-Gutierrez, E., Vargas-Torres, D., \& Clark, G. G. (2009). Community beliefs and practices about dengue in Puerto Rico. Revista Panamericana de Salud Pública, 25, 218-226.

Soegijanto, S. (2016). Kumpulan makalah penyakit tropis dan infeksi di Indonesia (Vol. 5). Airlangga University Press.

Spiegel, J., Bennett, S., Hattersley, L., Hayden, M. H., Kittayapong, P., Nalim, S., ... Gubler, D. (2005). Barriers and bridges to prevention and control of dengue: the need for a social-ecological approach. EcoHealth, 2(4), 273-290. 